\title{
ANALISIS TIMBRE RAPA'I BUATAN FAJAR SIDDIQ DI DESA KAYEE LHEU, KECAMATAN INGIN JAYA, KABUPATEN ACEH BESAR (KAJIAN MUSIK MULTIMEDIA)
}

\author{
Benny Andiko ${ }^{1^{*}}$, Berlian Denada ${ }^{2 *}$ \\ Jurusan Seni Pertunjukan \\ Institut Seni Budaya Indonesia Aceh \\ Jl. Transmigrasi, Gampong Buket Meusara, Kec. Kota Jantho, Kab. Aceh Besar, Kode Pos 23911 \\ Aceh. Indonesia \\ Email:bennyandiko99@gmail.com, berliandenada@isbiaceh.ac.id
}

\begin{abstract}
Abstrak
Penelitian ini berjudul "Analisis Timbre Rapa'i Buatan Fajar Siddiq di Desa Kayee Lheu, Ingin Jaya, Kabupaten Aceh Besar (Kajian Musik Multimedia). Penelitian ini bertujuan untuk mengetahui bentuk timbre Rapa'i buatan Fajar Siddiq, bagaimana tahapan perekaman timbre dan analisis timbre menggunakan Spectrum Analyzer pada software PreSonus Studio One 5. Memfokuskan pada kajian musik multimedia, mengadopsi topik bahasan tahapan perekaman dengan kategori yaitu: menurut sifatnya dan menurut peralatan tata suara. Proses awal rekaman musik yaitu tracking. Timbre tergantung terutama pada akustik stimulus, tetapi juga tergantung pada bentuk gelombang. Timbre mengacu pada dimensi bunyi yang memungkinkan pendengar mengindentifikasi sumber bunyi dan kandungan bunyi. Menggunakan pendekatan tahapan perekaman dari Ambrosius Yuniart Lefaan dan analisis timbre dari Pratt dan Doak. Metode penelitian yang digunakan dalam penelitian ini adalah penelitian kualitatif sebagai prosedur penelitian yang menghasilkan data deskriptif berupa informasi tertulis dan hasil analisis menggunakan Spectrum Analyzer. Menggunakan tahapan pengumpulan data yaitu: observasi; studi pustaka; wawancara dan dokumentasi. Hasil dan pembahasan dari penelitian ini yaitu; timbre Rapa'i yang terdiri dari empat warna bunyi (dum, preng, breuk dan crik) direkam menggunakan peralatan rekaman digital sebagai berikut; microphone condenser Audio Technica AT 2035 menggunakan teknik ambient miking, audio interface Zoom R24; teknik rekaman multitrack dengan track yang terpisah dari empat timbre Rapa'i; media penyampaian merupakan klasifikasi dari membranophone yaitu Rapa'i; media penyimpan DAW (Digital Audio Workstation) yaitu software PreSonus Studio One 5. Proses rekaman dengan tahapan tracking menggunakan empat channel dengan tipe rekam mono audio, sample rate $44.1 \mathrm{kHz}$ dengan resolusi 24 bit. Frekuensi fundamental timbre dum $172 \mathrm{~Hz}$ dengan SPL -17,8dB, preng $192 \mathrm{~Hz}$ dengan SPL -16,8dB, breuk $172 \mathrm{~Hz}$ dengan SPL -28,2dB dan crik $192 \mathrm{~Hz}$ dengan SPL $-22,3 \mathrm{~dB}$.
\end{abstract}

Kata Kunci: analisis, timbre, rapa'I, fajar siddiq.

\begin{abstract}
This research is entitled "Analysis of Timbre Rapa'i Made by Fajar Siddiq in Kayee Lheu Village, Ingin Jaya, Aceh Besar District. This study aims to determine the form of the Rapa'i timbre made by Fajar Siddiq, what are the steps for recording timbre and analyzing timbre using the Spectrum Analyzer on the PreSonus Studio One 5 software. Focusing on multimedia music studies, adopting the topic of recording stages with categories, namely; according to their nature and according to the sound system. The initial process of recording music is tracking. Timbre depends primarily on the acoustics of the stimulus, but also depends on the waveform. Timbre refers to the dimension of sound that allows the listener to identify the source of the sound and the content of the sound. Using a recording stage approach from Ambrosius Yuniart Lefaan and timbre analysis from Pratt and Doak. The research method used in this study is qualitative research as a research procedure that produces descriptive data in the form of written information and analysis results using a Spectrum Analyzer. Using the stages of data collection, namely: observation; literature review; interviews and documentation. The results and discussion of this research are; Rapa'i timbre which consists of four sound colors (dum, preng, breuk dan crik) recorded using digital recording equipment as follows; Audio Technica AT 2035 condenser microphone using ambient miking technique, Zoom R24 audio interface; multitrack recording technique with tracks separated from the four Rapa'i timbres; delivery media is a classification of membranophone namely Rapa'i; DAW (Digital Audio Workstation) storage media, namely PreSonus Studio One 5 software. The recording process with tracking stages uses four channels with mono audio recording type, $44.1 \mathrm{kHz}$ sample rate with 24 bit resolution. The fundamental frequency is timbre dum
\end{abstract}


Keywords: analysis, timbre, rapa'I, fajar, siddiq.

\section{PENDAHULUAN}

Berbicara tentang teknologi seolah tak lepas dari ilmu pengetahuan, karena memang pada hakikatnya teknologi adalah penerapan ilmu atau pengetahuan lain yang terorganisir ke tugas-tugas praktis. Sehingga dapat dipahami bahwa teknologi merupakan pengejawantahan dari ilmu pengetahuan. Dengan kata lain, jika ilmu pengetahuan berbicara dalam konteks teoritis, maka teknologi telah melakukan tataran praktisnya. (Sadiman. 2000). Berdasarkan hal ini teknologi dalam pemahaman peneliti merujuk pada teknologi musik yang berkembang pesat di Era Revolusi Industri 4.0. Fokus kajian teknologi musik khususnya instrumen tradisional sangat minim di tengah perkembangan pesat teknologi musik pada instrument modern.

Sejak terciptanya microchip dan teknologi komputer lainnya, sebagian pengguna menyadari potensi yang dapat dikembangkan oleh penemuan tersebut. Di dunia musik sendiri penemuan semua hal yang terkait digital telah berkembang sangat jauh, meskipun rata-rata konsep yang dikembangkan adalah mendigitalkan halhal yang analog, tetapi hal itu telah banyak membantu musisi dalam proses dan produksi. Salah satu contoh perkembangan teknologi yang ada di dunia musik adalah munculnya berbagai pilihan Digital Audio Workstation atau yang biasa disebut DAW. DAW (Digital Audio Workstation) software rekaman musik yang menghubungkan komputer dengan audio interface atau sound card. DAW (Digital Audio Workstation) perekaman yang bersifat digital dapat memudahkan musisi, composer, dan sound engineer dalam melakukan pekerjaannya. DAW (Digital Audio Workstation) adalah perangkat lunak produksi musik yang digunakan untuk merekam dan mengedit suara dalam bentuk file audio. File audio disimpan di perangkat keras komputer atau drive eksternal. Contoh aplikasi DAW adalah Audacity, GarageBand, Pro Tools, Logic, dan Cubase (Walzer, 1997).

$D A W$ adalah alat elektronik atau perangkat lunak yang didesain untuk mengakomodasi penggunanya untuk merekam, mixing, mastering dan mengubah suara yang telah direkam. Bermula pada pertengahan era 1970-an, perkembangan yang signifikan telah mengantarkannya pada teknologi yang mengagumkan. Produk-produk $D A W$ saat ini tidak hanya mampu menggantikan semua equipment yang ada dalam sebuah studio rekaman, tetapi juga mampu membuat proses produksi musik menjadi efektif dan efisien.

Pada penelitian ini $D A W$ akan digunakan untuk menganalisa kandungan bunyi timbre Rapa'i yaitu pada software PreSonus Studio One 5. Software ini dikembangkan oleh PreSonus dan tersedia untuk macOS dan Windows. Selain edisi komersial perangkat lunak (dikenal sebagai Studio One Artist dan Studio One Professional), PreSonus juga mendistribusikan edisi gratis, dengan fungsionalitas yang lebih rendah (dikenal sebagai Studio One Prime). Sementara untuk menganalisa frekuensi fundamental timbre Rapa'i akan menggunakan Studio One Professional. Fungsionalitas yang lengkap dengan tersedianya Spectrum Analyzer sebagai media analisis timbre Rapa'i. Spectrum analyzer merupakan sebuah penerima sinyal secara pasif, yang berarti sinyal yang diterima hanya ditampilkan saja untuk mengukur sinyal elektrik yang melalui atau ditransmisikan oleh sebuah sistem/perangkat. Sinyal yang ditampilkan oleh spectrum analyzer akan dianalisis oleh pengguna untuk mengetahui karakteristik sinyal tersebut. Pada penelitian ini Spectrum Analyzer akan digunakan untuk menganalisis kandungan bunyi dari timbre Rapa'i buatan Fajar Siddiq.

Rapa'I sebagai salah satu nama instrumen musik pukul terbuat dari kayu Tualang atau Merbau, sedangkan membrannya terbuat dari kulit kambing atau lembu yang diolah. Awalnya rapa'i lahir sebagai salah satu bentuk kesenian yang dimanfaatkan untuk mengembangkan ajaran agama Islam (Ediwar, 2016). Satu-satunya pengrajin alat musik Aceh yaitu Rapa'i di Kabupaten Aceh Besar bernama Fajar Siddiq. Sebagai pengrajin Rapa'i, Fajar Siddiq telah mendedikasikan hidupnya dari tahun 1994. Terhitung di tahun $2021 \mathrm{ini}$, sudah 27 tahun beliau menjalani dinamika pembuatan Rapa'i. Mengandalkan peralatan dan perlengkapan sederhana Rapa'i buatan Fajar Siddiq telah tersebar ke penjuru tanah air dan luar negeri seperti Jepang, Australia dan Amerika Serikat. Tentunya melalui Rapa'i buatan beliau, sejarah panggung seni pertunjukan tercipta dalam sebaran ruang dan waktu. Selain sebagai pengrajin Rapa'i, beliau juga mahir memainkan alat musik Aceh tersebut. Beliau pernah tergabung dalam beberapa grup kesenian seperti Nyawong, Kande dan Rakit. Pengalaman dan kemahiran dalam memainkan alat musik tersebut juga 
merupakan faktor penentu untuk menghasilkan Rapa'i yang berkualitas. Rapai merupakan alat musik membranofon yang produksi bunyinya dihasilkan dengan memukul bagian selaput atau membran. Bunyi yang dihasilkan Rapa'i menghasilkan timbre yang khas.

Timbre adalah atribut sensasi pendengaran dimana pendengar dapat menilai bahwa dua bunyi yang berbeda menggunakan kriteria selain ruang, kenyaringan atau durasi (Rossing, 1990). Pendapat tersebut menunjukkan bahwa penilaian timbre berlangsung dalam kondisi kenyaringan yang sama, pitch dan durasi yang mungkin juga sama. Sebuah penjelasan ditambahkan (Pratt dan Doak dalam Rossing, 1990): Timbre tergantung terutama pada akustik stimulus, tetapi juga tergantung pada bentuk gelombang. Timbre mengacu pada dimensi bunyi yang memungkinkan pendengar mengindentifikasi kandungan bunyi dan sumber bunyi.

Merujuk pada penjelasan tersebut dalam timbre terdapat kandungan bunyi dan sumber bunyi yaitu Rapa'i buatan Fajar Siddiq di Desa Kayee Lheu, Ingin Jaya, Kabupaten Aceh Besar.

Berdasarkan penjabaran di atas, maka penelitian ini merupakan tahapan awal dari proses pencarian data kandungan bunyi dengan sumber bunyi dari timbre Rapa'i. Rumusan masalah dalam penelitian ini, yaitu: Pertama: bagaimana proses perekaman timbre Rapa'i buatan Fajar Siddiq di Desa Kayee Lheu, Ingin Jaya, Kabupaten Aceh Besar. Kedua, bagaimana bentuk kandungan bunyi timbre Rapa'i buatan Fajar Siddiq di Desa Kayee Lheu, Ingin Jaya, Kabupaten Aceh Besar.

Penelitian ini merupakan rangkaian data dari kandungan bunyi pada Plugin VST (Virtual Studio Technology) dari Rapa'i agar bunyi yang dihasilkan lebih manusiawi. VST pada dasarnya diciptakan untuk meniru berbagai peralatan perangkat keras yang digunakan di studio. Istilah Plugin mengacu pada perangkat lunak yang beroperasi dalam program lain. Plugin VST telah membuat proses pembuatan musik jauh lebih sederhana dan jauh lebih mudah diakses. Di masa lalu produksi dan pembelajaran akan membutuhkan perangkat keras dan peralatan yang hampir tidak dapat diakses oleh sebagian besar pengguna dikarenakan implikasi biaya. Plugin VST hadir dengan konsep hemat dan kompetitif dengan perangkat keras. Plugin VST tersebut akan digunakan sebagai media pembelajaran mata kuliah di Prodi Seni Karawitan, seperti mata kuliah Teknologi Musik, Musik Elektronik, dan Komposisi Musik. Plugin VST
Rapa'i ini juga akan bermanfaat dalam proses produksi musik secara global. Penelitian ini mengungkap proses perekaman dan bentuk kandungan bunyi dari timbre Rapa'i buatan Fajar Siddiq di Desa Kayee Lheu, Ingin Jaya, Kabupaten Aceh Besar.

\section{KAJIAN TEORI}

\section{Perekaman}

Perekaman adalah keterampilan dalam menggabungkan seni dan sains, yang membutuhkan pengetahuan teknis serta pengetahuan musik dan kemampuan mendengarkan suara. Dengan mempelajari keterampilan ini, kita dapat mengabadikan penampilan musik, dan memproduksi kembali dengan kualitas suara yang dapat dinikmati dan menginspirasi orang lain (Bartlett, 2009).

Unsur-Unsur rekaman musik memiliki beragam jenis dan terbagi menjadi beberapa kategori yaitu: menurut sifatnya dan menurut peralatan tata suara. Berdasarkan sifatnya rekaman musik terbagi dalam jenis peralatan (rekaman analog dan rekaman digital) dan teknik rekaman (rekaman live dan rekaman multirack). Berdasarkan peralatan tata suara terdiri dari media penyampaian (pita suara dan alat musik) dan media penyimpan (DAT [Digital Audio Tape] dan DAW [Digital Audio Workstation]). Proses rekaman musik terdapat tahapan standar yang dilakukan, yaitu: tracking, overdub, editing, mixing, equalizing, sound effect dan mastering (Lefaan, 2010).

Penelitian ini mengadopsi pengetahuan teknis perekaman tersebut untuk merekam timbre Rapa'i buatan Fajar Siddiq. Perekaman dilakukan dengan penambahan beberapa media pendukung lainnya.

\section{Analisis Timbre}

Timbre tergantung terutama pada akustik stimulus, tetapi juga tergantung pada bentuk gelombang. Timbre mengacu pada dimensi bunyi yang memungkinkan pendengar mengindentifikasi sumber bunyi dan kandungan bunyi. (Pratt dan Doak dalam Rossing, 1990).

Timbre adalah atribut sensasi pendengaran dimana pendengar dapat menilai bahwa dua bunyi yang berbeda menggunakan kriteria selain ruang, kenyaringan atau durasi (Rossing, 1990). Hal ini menunjukkan bahwa penilaian timbre berlangsung dalam kondisi kenyaringan yang sama, pitch dan durasi yang mungkin juga sama. Penulis menggunakan Spectrum Analyzer pada software Presonus Studio One 5 untuk mengindentifikasi kandungan bunyi dari timbre 
Rapa'i buatan Fajar Siddiq di Desa Kayee Lheu, Ingin Jaya, Kabupaten Aceh Besar (Siddiq, 2021).

\section{METODE PENELITIAN}

Metode penelitian pada umumnya terbagi kepada dua metode yang lazim digunakan yaitu metode penelitian kualitatif dan metode penelitian kuantitatif. Metode penelitian ini menggunakan metode penelitian kualitatif. Bogdan dan Taylor mendefinisikan penelitian kualitatif sebagai prosedur yang menghasilkan data deskriptif berupa kata-kata tertulis atau lisan dari orang-orang dan perilaku yang dapat diamati (Bogdan dan Taylor dalam Moleong. 1995). Untuk mendukung metode penelitian kualitatif sebagai metode penelitian yang telah dipilih, maka juga dilakukan beberapa tahapan penelitian. Adapun beberapa tahapan sesuai dengan dikemukakan oleh Bogdan. Ia menyajikan tiga tahapan dalammelakukan proses penelitian kualitatif, yaitu: (1). Pralapangan; (2). Kegiatan lapangan; (3). Dan analisis intensif (Bogdan dan Taylor dalam Moleong. 1995). Terkait proses penelitian ini telah dilakukan beberapa langkah sebagai bagian dari beberapa tahap penelitian sesuai dengan yang dinyatakan Bogdan.

Tahap pra lapangan ini berbentuk studi pustaka yang menjadi langkah awal dalam melakukan suatu penelitian pada tahap ini. Studi pustaka sangat berguna untuk mengetahui apakah objek serta permasalahan yang akan diteliti ini sebelumnya sudah diteliti sebelumnya. Tahapan ini akan diawali dengan mengumpulkan referensi-referensi berupa buku, majalah, jurnal dan sumber tertulis lainnya guna memperkuat penelitian tersebut yang nantinya akan dituangkan ke dalam bentuk tulisan. Di samping itu juga menjadi pedoman dan pendukung dalam melaksanakan penelitian tentang "Analisis Timbre Rapa'i Buatan Fajar Siddiq di Desa Kayee Lheu, Ingin Jaya, Kabupaten Aceh Besar".

Langkah selanjutnya adalah tahap kerja lapangan untuk mengumpulkan data yang akan dianalisis menjadi sebuah bentuk laporan. Dengan melakukan studi lapangan yaitu pengumpulan data-data dengan cara melakukan observasi, wawancara serta pendokumentasian audio dan visual yang mengunakan alat dokumentasi audio seperangkat alat media rekam audio, kamera foto dan kamera video.

Dalam tahap kerja lapangan atau diistilahkan dengan studi lapangan ini ditempuh melalui beberapa tahaptahap sebagai berikut: Terkait dengan pentingnya langkah observasi (pengamatan) dalam setiap penelitian. Terkait hal ini penulis mengamati secara langsung sumber bunyi, teknik produksi bunyi dan timbre Rapa'i buatan Fajar Siddiq di Desa Kayee Lheu, Ingin Jaya, Kabupaten Aceh Besar. Gunanya sebagai pendukung terhadap data yang diperoleh dalam studi pustaka pada tahap pra lapangan, sekaligus untuk meminimalisir keraguan agar tidak terjadinya bias data yang diperoleh sebelum penelitian lewat studi pustaka yang dilakukan.

Proses dalam tahap wawancara akan dilakukan dalam bentuk tanya jawab antara penulis dan informan, dalam hal ini bersama Fajar Siddiq pembuat Rapa'i di Desa Kayee Lheu, Ingin Jaya, Kabupaten Aceh Besar. Wawancara berkaitan langsung dengan objek dan fokus penelitian yang diteliti.

Proses pendokumentasian sangat penting guna membantu melengkapi data-data sebagai penunjang suatu penelitian dalam tahapan lanjutan analisis dan pengolahan data yang didapat di lapangan nantinya. Proses pendokumentasian mengunakan instrumen penelitian. Tahapan ini dilakukan dengan memanfaatkan alat dokumentasi seperangkat alat media rekam audio, kamera foto dan kamera video.

Setelah mendapatkan data-data tentang objek yang akan diteliti melalui narasumber yang telah ditemui selama proses penelitian tentang Analisis Timbre Rapa'i Buatan Fajar Siddiq di Desa Kayee Lheu, Ingin Jaya, Kabupaten Aceh Besar berlangsung, maupun dari sumber-sumber lain seperti dari jurnal, laporan penelitian, buku, dan skripsi. Selanjutnya data-data tersebut akan dipilih dan dilakukan penyisihan untuk kemudian dianalisis. Data-data yang dianalisis kemudian disusun menjadi sebuah laporan penelitian.

\section{HASIL DAN PEMBAHASAN \\ 1.Hasil}

Berdasarkan hasil observasi, wawancara dan pendokumentasian audio dan visual yang telah dilakukan pada bagian penelitian Analisis Timbre Rapa'i Buatan Fajar Siddiq di Desa Kayee Lheu, Ingin Jaya, Kabupaten Aceh Besar sebagai berikut: berdasarkan teknik produksi bunyi terdapat empat warna bunyi yaitu dum, preng, breuk dan crik. Warna bunyi yang pertama, dum. Dum dihasilkan dengan cara memukul dengan 4 jari pada bagian tengah Rapa'i. Bunyi menyerupai bunyi beat (bass). Kedua, preng. Bunyi preng dihasilkan dengan cara memukul kulit pada bagian pinggir Rapa'i. Untuk menghasilkan bunyi preng digunakan 4 jari saat memukulkan. Ketiga, breuk. Suara breuk dihasilkan dengan cara memukul tengah Rapa'i. Tapi untuk menghasilkan bunyi breuk tangan harus ditempelkan agar suara breuk kita 
dapatkan. Keempat, crik. Bunyi crik dihasilkan dengan cara memukul bagian bingke (bingkai) tanpa mengenai kulit Rapa'i. (Fajar Siddiq, 2021).

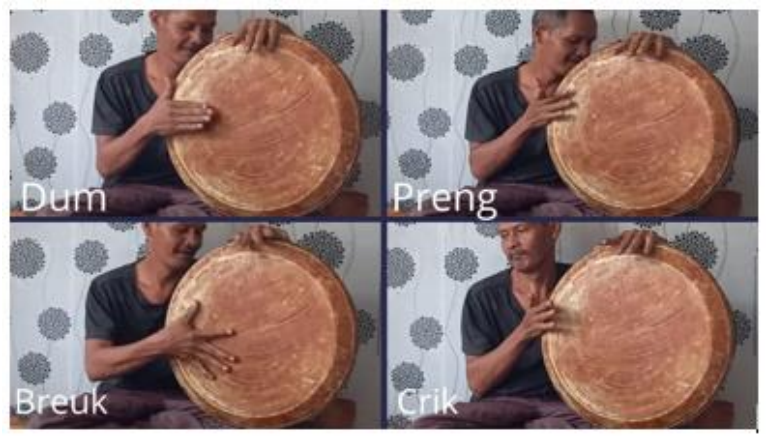

Gambar 1. Empat Warna Bunyi Rapa'I (Andiko, 2021)

Timbre Rapa'i buatan Fajar Siddiq direkam menggunakan unsur-unsur dan tahapan rekaman. Selanjutnya, hasil rekaman tersebut dianalisis menggunakan Spectrum Analyzer pada software PreSonus Studio One 5 untuk mengetahui kandungan bunyi dari timbre Rapa'i buatan Fajar Siddiq.

\section{Pembahasan}

\section{1). Perekaman Timbre Rapa'I Buatan Fajar Siddiq}

Rekaman adalah keterampilan dalam menggabungkan seni dan sains, yang membutuhkan pengetahuan teknis serta pengetahuan musik dan kemampuan mendengarkan suara. Dengan mempelajari keterampilan ini, kita dapat mengabadikan penampilan musik, dan memproduksi kembali dengan kualitas suara yang dapat dinikmati dan menginspirasi orang lain (Bartlett, 2009). Rekaman musik saat ini merupakan keterampilan kompleksitas dari pengetahuan musik, tata suara, akustik, fisika dan teknologi. Unsur-unsur rekaman musik memiliki beragam jenis dan terbagi menjadi beberapa kategori yaitu: menurut sifatnya dan menurut peralatan tata suara. Berdasarkan sifatnya rekaman musik terbagi dalam jenis peralatan (rekaman analog dan rekaman digital) dan teknik rekaman (rekaman live dan rekaman multirack). Berdasarkan peralatan tata suara terdiri dari media penyampaian (pita suara dan alat musik) dan media penyimpan (DAT [Digital Audio Tape] dan DAW [Digital Audio Workstation]). Proses rekaman musik terdapat tahapan standar yang dilakukan, yaitu: tracking, overdub, editing, mixing, equalizing, sound effect dan mastering (Lefaan, 2010).

Peralatan perekaman terdiri dari rekaman analog dan rekaman digital. Rekaman analog merupakan rekaman dengan sistem analog dilakukan dengan menggunakan perangkat berupa tape recording. Rekaman analog
Gorga : Jurnal Seni Rupa

Volume 10 Nomor 02 Juli-Desember 2021 p-ISSN: 2301-5942 | e-ISSN: 2580-2380

dapat menghasilkan suara lebih tebal karena menggunakan pita vinyl. Sistem ini lebih mudah dan ringkas. Sementara rekaman digital merupakan sistem rekaman yang secara langsung dapat mengkonversi sinyal analog dari instrumen dan vokal ke dalam format midi. Media perangkat digital menggunakan perangkat software dan hardware. Berdasarkan jenis peralatan tersebut, penelitian ini menggunakan jenis peralatan rekaman digital. Berikut ini peralatan rekaman digital pada perekaman timbre Rapa'i buatan Fajar Siddiq.

\section{(1). Mikrofon (Desain, Karakteristik, dan Teknik)}

Mikrofon adalah transduser yang mengubah energi suara akustik menjadi energi listrik. Transduser elektromagnetik memudahkan konversi sinyal akustik menjadi sinyal listrik. Mereka juga bertindak untuk mengubah sinyal listrik kembali menjadi gelombang suara akustik. Prinsipnya sangat sederhana: jika kawat bisa dibuat bergerak di medan magnet, tegak lurus dengan garis fluks yang menghubungkan kutub magnet, maka arus listrik diinduksi di kawat. Arah gerak mengatur arah arus arus di kawat. Jika kawat dapat dibuat untuk bergerak maju mundur maka arus bolak dapat diinduksi pada kawat, yang terkait dengan frekuensi dan amplitudo pada gerak kawat. Sebaliknya, jika arus dibuat mengalir melalui kawat yang memotong garis medan magnet maka kawat akan bergerak. Ia melakukan fungsi berlawanan ke loudspeaker, yang mengubah energi listrik menjadi energi akustik (Rumsey, 2009). Berbagai tipe mikrofon yang masing-masing tipe menggunakan metode yang berbeda dalam mengkonversi energi, namun semua tipe mikrofon memiliki satu kesamaan yaitu diafragma. Diafragma merupakan sebuah material tipis (berupa kertas, plastic atau aluminium) yang bergetar ketika terkena gelombang suara. Saat diafragma bergetar, komponen lain dalam mikrofon ikut bergetar. Getaran ini dikonversi menjadi arus listrik yang kemudian menjadi sinyal audio. Berdasarkan uraian tersebut fokus bahasan mengenai desain, karakteristik dan teknik mikrofon terkait analisis timbre Rapa'i buatan Fajar Siddiq sebagai berikut:

\section{a. Desain Mikrofon}

Berdasarkan jenis desainnya, mikrofon yang digunakan sebagai perangkat pertama media rekam timbre Rapa' $i$ buatan Fajar Siddiq yaitu condenser microphone. Hal ini disesuaikan dengan kebutuhan pada saat perekaman menggunakan mikrofon Audio Technica AT2035. Gambar berikut merupakan condenser mic tersebut. 

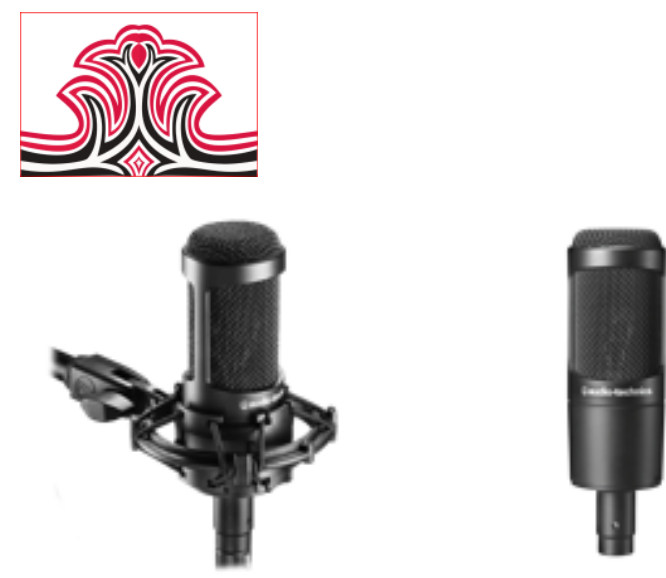

Gambar 2. Audio Technica AT2035 Condenser Microphone

(Technica, 2021)

Mic Audio Technica AT2035 dirancang untuk perekaman menggunakan aplikasi professional studio dan pertunjukan langsung, mikrofon ini memberikan detail yang luar biasa dan kebisingan yang rendah. Dilengkapi dengan filter high-pass $80 \mathrm{~Hz}$ dan pad 10 dB yang dapat dialihkan. AT2035 menangani tingkat tekanan suara yang tinggi dengan mudah. Seiring dengan konstruksi yang kokoh dan spesifikasi performa tinggi, memberikan tingkat konsistensi yang luar biasa dari model ke model. Dilengkapi dengan kantong pelindung dan shock mount khusus.

Elemen AT2035 ini tetap isi ulang pelat belakang, kondenser terpolarisasi permanen. Pollar pattern AT2035 merupakan cardiod dengan frekuensi respon 20-20.000 Hz. Roll off frekuensi rendah $80 \mathrm{~Hz}$ dan 12 dB/octave. Audio Technica (2021). Berdasarkan penjelasan tersebut, condenser mic (mikrofon kondenser) Audio Technica AT2035 merupakan pilihan perangkat pertama perekaman bunyi timbre Rapa'i buatan Fajar Siddiq. Karakteristik mikrofon yang bisa digunakan untuk merekam instrumen akustik dan vokal pada umumnya. Pembahasan selanjutnya mengenai karakteristik condenser mic (mikrofon kondenser) Audio Technica AT2035.

\section{b. Karakteristik Mikrofon}

\section{a). Direction Response}

Arah mikrofon dapat dikelompokkan menjadi dua kategori: respon polar omnidirectional dan respon polar directional (Huber, 2010). Mikrofon omnidirectional adalah alat yang dioperasikan dengan tekanan yang responsif terhadap suara yang berasal dari segala arah. Dengan kata lain, diafragma akan bereaksi sama terhadap semua fluktuasi tekanan suara di permukaannya, terlepas dari lokasi sumbernya. Pickups yang menampilkan directional properties adalah perangkat tekanan-gradien, yang berarti bahwa pickup responsif terhadap perbedaan tekanan yang relatif antara depan, belakang dan sisi diafragma. Sebenarnya, sejumlah pola arah tak terhingga dapat diperoleh dari
Gorga : Jurnal Seni Rupa

Volume 10 Nomor 02 Juli-Desember 2021

p-ISSN: 2301-5942 | e-ISSN: 2580-2380

campuran ini, dengan pola yang paling banyak dikenal sebagai pola kutub cardioid, supercardioid dan hypercardioid. Gambar berikut merupakan polar pattern mikrofon kondenser AT 2035.

\section{AT2035}

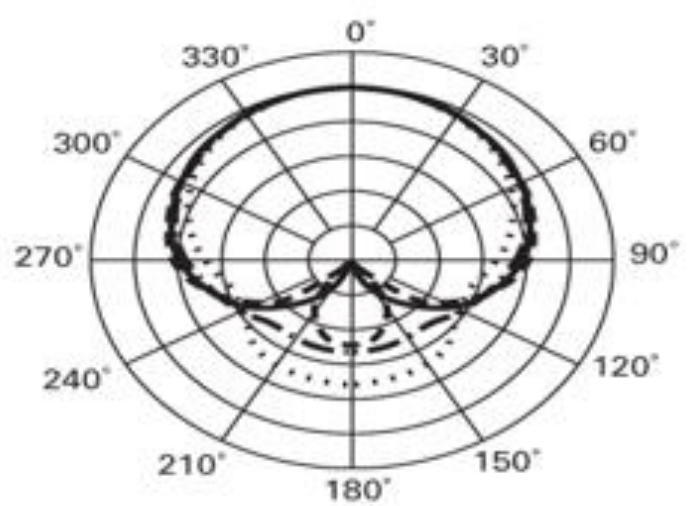

SCALE IS 5 DECIBELS PER DIVISION

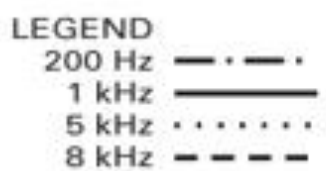

Gambar 3. Pollar Pattern AT2035 (Technica, 2021)

Mikrofon condenser Audio Technica AT2035 merupakan kategori cardioid polar pattern. Respon cardioid (dinamai berdasarkan grafik kutub berbentuk hati) dengan memasukkan port belakang ke dalam desainnya. Port ini berfungsi sebagai labirin akustik yang menciptakan ketahanan akustik (delay).

\section{b). Frequency Response}

Frequency response mikrofon didefinisikan sebagai rentang suara (dari frekuensi terendah hingga tertinggi) yang dapat dihasilkan dan variasinya di antara rentang tersebut. Ada dua tipe respon frekuensi yang sudah sangat umum, yaitu flat dan shaped. Mikrofon memberikan output yang uniform pada setiap frekuensi audio disebut respon frekuensi flat. Respon frekuensi ini direpresentasikan pada grafik respon frekuensi sebagai sebuah garis lurus. Artinya, mikrofon menghasilkan suara dalam rentang frekuensinya (frequency range) dengan variasi yang kecil dan bahkan tidak ada variasi dari suara aslinya. Sebaliknya, mikrofon dengan respon frekuensi shaped memiliki bentuk grafik berupa garis yang bervariasi yang terdiri dari "gunung-lembah" yang spesifik.

Pemilihan mikrofon dengan sifat respon frekuensi harus mempertimbangkan sumber suara dan tujuan dari suara tersebut. Rentang frekuensi (frequency range) 
dari mikrofon harus cukup lebar untuk menghasilkan suara dengan rentang yang diinginkan. High-quality sound system dengan rentang frekuensi yang lebar. Sementara itu, untuk keperluan pidato cukup digunakan mikrofon dengan frekuensi yang lebih sempit.

Shaped response umumnya digunakan untuk vocal dengan rentang frekuensi yang sesuai dengan rentang suara manusia. Selain itu, mikrofon yang ditodongkan pada instrumen-instrumen tertentu seperti drum dan ampli gitar merupakan shaped response microphone yang respon frekuensinya disesuaikan dengan respon frekuensi suara instrumen tersebut. Gambar berikut merupakan frequency response mikrofon condenser AT 2035 dari Audio Technica.

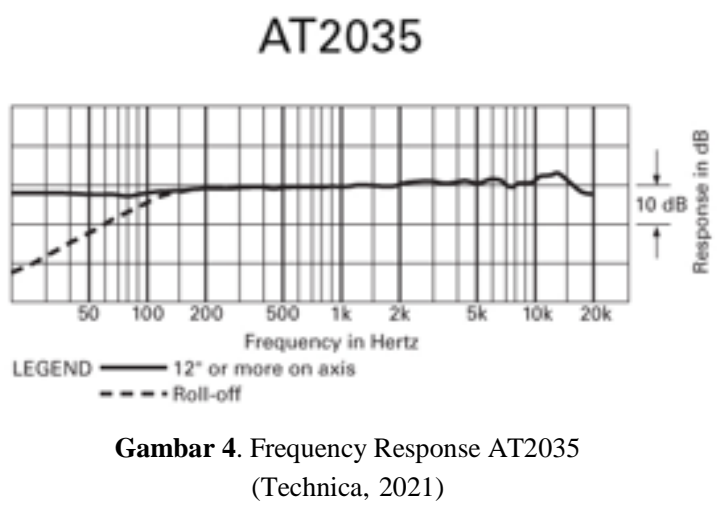

Data Technica (2021) menyatakan mikrofon condenser AT2035 bersifat frequency response flat. Di dalam penggunaannya, flat response microphone direkomendasikan untuk keperluan instrumen akustik, paduan suara dan orkestra, khususnya ketika harus ditempatkan pada jarak tertentu dari sumber suara dengan cara ditodongkan. Berdasarkan karakternya mikrofon condenser AT2035 digunakan sebagai perangkat pertama perekaman timbre Rapa'i buatan Fajar Siddiq.

\section{c). Teknik Mikrofon}

Mikrofon memiliki karakter suara khas yang didasarkan pada jenis dan desain spesifiknya. Berbagai jenis dan model mikrofon digunakan untuk berbagai aplikasi. Tergantung kepada sound engineer (teknisi suara/bunyi) untuk memilih yang cocok dengan produksi audio. Hal dapat ditemukan dalam kategori memilih rangkaian mikrofon terbatas yang sesuai untuk berbagai aplikasi dan memperoleh koleksi besar mikrofon yang umumnya dianggap cocok secara individu untuk instrumen atau situasi tertentu. Karakteristik pengambilan audio sebagai fungsi jarak kerja di studio dan di luar studio, empat teknik dasar penempatan mikrofon berhubungan langsung dengan
Gorga : Jurnal Seni Rupa

Volume 10 Nomor 02 Juli-Desember 2021

p-ISSN: 2301-5942 | e-ISSN: 2580-2380

jarak kerja mikrofon dari sumber suaranya. Empat teknik miking: (1) distant miking (2) close miking (3) accent miking (4) ambient miking (Hubber, 2010). Posisi mikrofon pada perekaman timbre Rapa'i buatan Fajar Siddiq menggunakan ambient miking (miking ambien). Pemilihan ambient miking bertujuan untuk mendapatkan sample bunyi Rapa'i dari berbagai arah. Gambar berikut merupakan posisi mikrofon pada perekaman timbre Rapa'i buatan Fajar Siddiq.

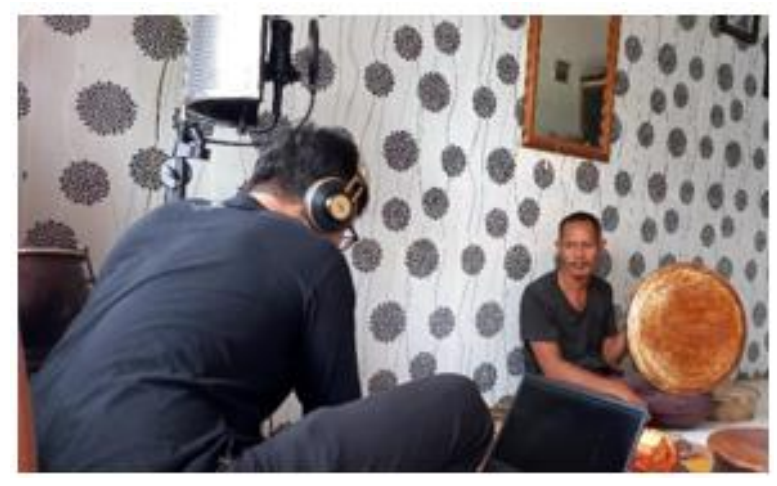

Gambar 5. Ambient Miking (Andiko, 2021)

Pemasangan mikrofon di tempat membuat pickup pada jarak sedemikian jauh sehingga suara reverberant atau room sama atau lebih menonjol daripada sinyal langsung. Penjumlahan ambien sering kali merupakan sepasang stereo kardio atau sepasang angka-8 (Blumlein) yang bisa dicampur menjadi produksi stereo atau surround sound untuk menghasilkan reverb alami dan / atau suasana (Hubber, 2010). Perekaman dilakukan di bengkel pembuatan Rapa'i milik Fajar Siddiq dengan tujuan timbre yang direkam berasal dari tempat pembuatannya. Posisi ambient miking menjadi pilihan untuk perekaman timbre. Jarak instrument dengan mic condenser menggunakan teknik ambient miking disesuaikan dengan kondisi ruangan untuk menghasilkan reverb atau suasana yang alami.

\section{(2). Audio Interface/ Sound Card}

Sound card terpadu biasanya berisi semua komponen yang diperlukan untuk menangani audio untuk keperluan dasar dalam komputer dekstop dan mungkin dapat beroperasi dalam mode dupleks penuh (masuk dan keluar pada saat yang bersamaan). Mereka biasanya menggabungkan konverter, DSP, antarmuka digital, FM dan mesin sintesis wavetable. Opsional, mereka mungkin juga menyertakan semacam papan putri I/O yang dapat dihubungkan ke antarmuka audio putus-putus, meningkatkan jumlah konektor yang mungkin dan pilihan untuk konversi analog eksternal. Kartu seperti itu juga cenderung sport MIDI / joystick interface. Contoh khas dari jenis kartu ini adalah seri 'SoundBlaster' dari Creative Labs (Rumsey, 2009). 
Audio interfacel sound card dalam berbagai bentuk, ukuran dan fungsi misalnya; (1) dipasangkan ke komputer atau laptop (perangkat ini seringkali terbatas pada kualitas dan fungsionalitas), (2) sederhana (dua perangkat audio), (3) multichannel, menawarkan delapan analog dan banyak pilihan ekspansi, (4) dilengkapi dengan satu atau lebih port MIDI, (5) Menawarkan opsi digital, jam kata dan sinkronisasi. Audio interface/ sound card dari Zoom R24 digunakan sebagai perangkat kedua perekaman timbre Rapa'i buatan Fajar Siddiq. Gambar berikut merupakan audio interface Zoom R24.

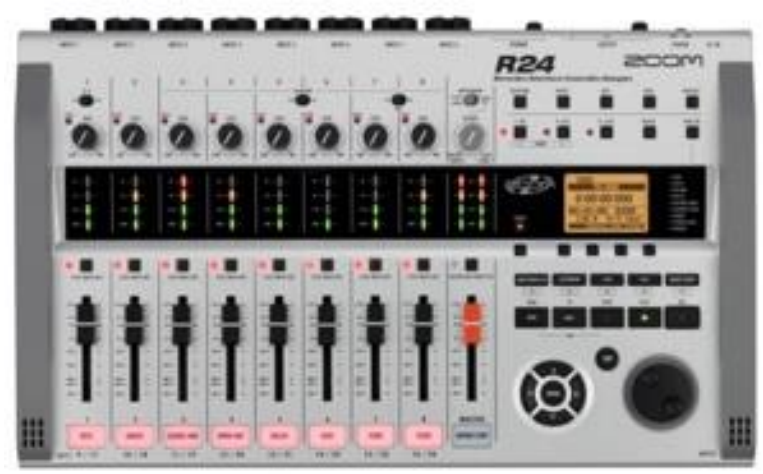

Gambar 6. Audio Interface/ Sound Card (Zoomtech, 2021)

Berdasarkan fiturnya, audio interface ZOOM R24 ini digunakan sebagai media penghubung dunia luar audio analog dari timbre Rapa'i dan dunia terdalam komputer dari audio digital.

Teknik rekaman terdiri dari rekaman live dan rekaman multirack. Rekaman live suatu teknik rekaman dimana semua suara yang dihasilkan, direkam dalam satu track. Kelebihan dari teknik rekaman live adalah para musisi mendapatkan feel dan energy dari lagu yang direkam karena memainkan alat musik secara bersamaan. Sedangkan kelemahannya adalah permainan musik harus benar-benar kompak. Semua personil dituntut untuk menguasai materi dengan benar, karena dalam teknik ini kesalahan tidak dapat dilakukan editing melainkan harus mengulang dari awal. Sementara rekaman multirack suatu teknik perekaman dimana masing-masing instrumen direkam secara bergantian dan disimpan pada track yang terpisah. Dalam teknik ini, musisi dapat mengulang part-nya berulang kali. Bahkan apabila terdapat kesalahan, musisi tidak perlu mengulang seluruh bagian lagu. Berdasarkan teknik rekaman tersebut, penelitian ini menggunakan teknik rekaman multitrack dengan track yang terpisah dari timbre Rapa'i buatan Fajar Siddiq. Gambar berikut tangkapan layar teknik rekaman multitrack dari timbre Rapa'i buatan Fajar Siddiq.

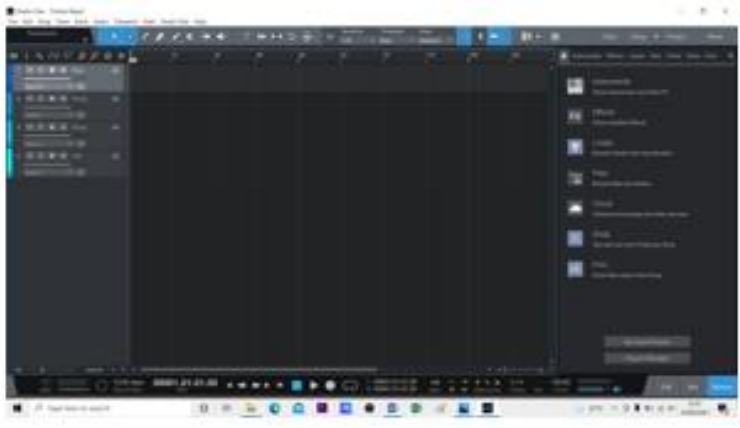

Gambar 7. Tangkapan Layar Rekaman Multirack Timbre Rapa'I (Andiko, 2021)

Media penyampaian terdiri atas pita suara dan alat musik. Pita suara dihasilkan dari getaran pita suara yang terdapat pada daerah tenggorokan manusia. Sementara untuk alat musik menurut Curt Sachs dan Hornbostel terbagi dalam empat klasifikasi yaitu : (1) Idiophone (penghasil bunyi adalah badan alat musik itu sendiri) ; (2) Membranophone (penghasil bunyi disebabkan oleh getaran kulit yang direnggangkan) ; (3) Kordophone (penghasil bunyi adalah dari getaran senar dawainya) ; (4) Aerophone (penghasil bunyi karena adanya sentuhan udara). Berdasarkan kriteria tersebut, maka alat musik Rapa'i termasuk kedalam klasifikasi membranophone. Berdasarkan jumlah dari membrannya membranophone dibagi lagi kedalam dua jenis yaitu single head dan double head (Sachs, 1914). Dalam klasifikasi ini Rapa'i merupakan membranophone single head karena hanya mempunyai satu membran. Berdasarkan media penyampaian tersebut, penelitian ini menggunakan media penyampaian alat musik yaitu Rapa'i buatan Fajar Siddiq. Gambar berikut ini merupakan Rapa'i buatan Fajar Siddiq.

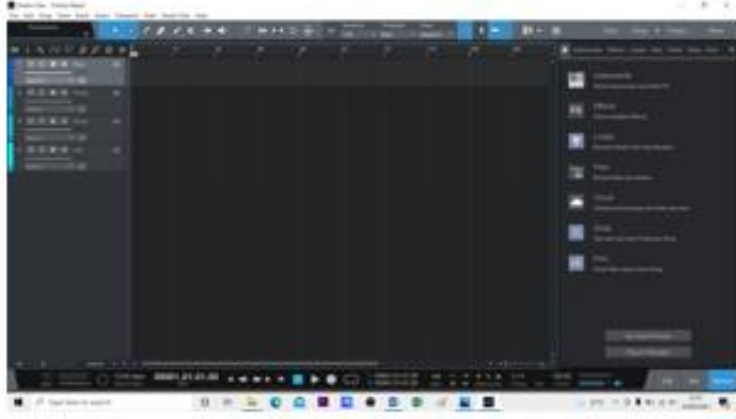

Gambar 8. Tangkapan Layar Rekaman Multirack Timbre Rapa'I (Andiko, 2021)

Media penyampaian terdiri atas pita suara dan alat musik. Pita suara dihasilkan dari getaran pita suara yang terdapat pada daerah tenggorokan manusia. Sementara untuk alat musik menurut Curt Sachs dan 
Hornbostel terbagi dalam empat klasifikasi yaitu : (1) Idiophone (penghasil bunyi adalah badan alat musik itu sendiri) ; (2) Membranophone (penghasil bunyi disebabkan oleh getaran kulit yang direnggangkan) ; (3) Kordophone (penghasil bunyi adalah dari getaran senar dawainya) ; (4) Aerophone (penghasil bunyi karena adanya sentuhan udara). Berdasarkan kriteria tersebut, maka alat musik Rapa'i termasuk kedalam klasifikasi membranophone. Berdasarkan jumlah dari membrannya membranophone dibagi lagi kedalam dua jenis yaitu single head dan double head (Sachs, 1914). Dalam klasifikasi ini Rapa'i merupakan membranophone single head karena hanya mempunyai satu membran. Berdasarkan media penyampaian tersebut, penelitian ini menggunakan media penyampaian alat musik yaitu Rapa'i buatan Fajar Siddiq. Gambar berikut ini merupakan Rapa'i buatan Fajar Siddiq.

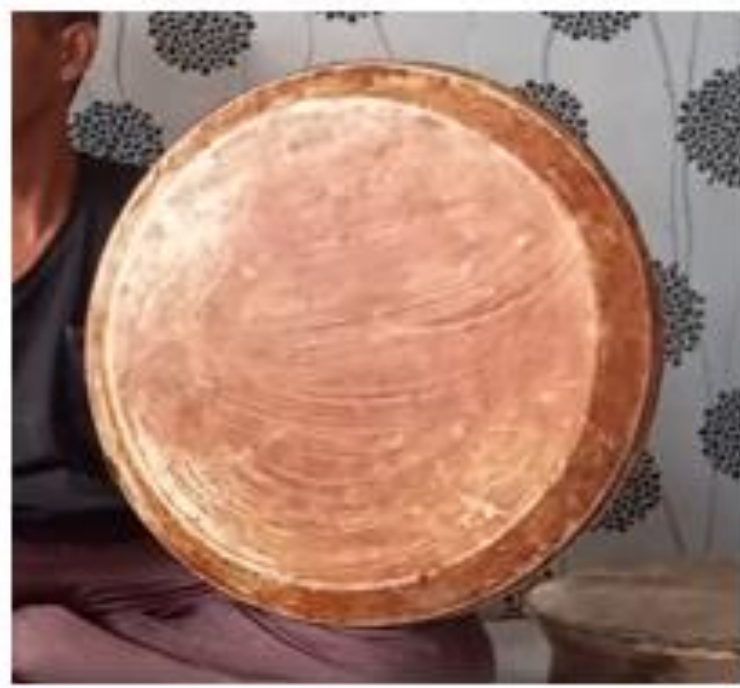

Gambar 9. Media Penyampai: Rapa'i (Andiko, 2021)

Bagian-bagian Rapa'i terdiri dari kulit/membran, baloh, paleung/babah, bohgrik/kerincing dan geup/bingke. (Rizky Riantori Syahreza. 2013: 50). Mencermati organologi instrument Rapa'i, sumber bunyinya berasal dari membran kulit tunggal yang terpasang pada kayu berbentuk lingkaran. Bagianbagian tersebut diintegrasikan melalui beberapa proses pembuatan. Proses pembuatan menggunakan beberapa peralatan yang didesain sendiri oleh Fajar Siddiq. Berdasarkan tingkat kerumitan proses pembuatan dan peralatan yang digunakan menjadikan Fajar Siddiq saat ini sebagai satu-satu pembuat Rapa'i khususnya di Kabupaten Aceh Besar dan Kota Banda Aceh. Ciri khas Rapa'i buatan Fajar Siddiq pada bagian bingkai yang dipasang dengan cara dipasak dan terlebih dahulu diberi lilitan kain sarung pada bagian dalamnya. Hal ini bertujuan untuk ketahanan dan kecepatan pembuatan
Gorga : Jurnal Seni Rupa

Volume 10 Nomor 02 Juli-Desember 2021 p-ISSN: 2301-5942 | e-ISSN: 2580-2380

Rapa'i tersebut. Sebagai seorang pemain Rapa'i dan pengalaman membuat Rapa'i selama kurang lebih 25 tahun menjadi tolak ukur kualitas Rapa'i buatan Fajar Siddiq. Baik dari segi material dan empat warna bunyi yang dihasilkan.

Media penyimpan terdiri dari DAT (Digital Audio Tape) dan DAW (Digital Audio Workstation). DAT (Digital Audio Tape) penyimpanan dengan menggunakan pita vinyl, dan karya musik direkam dalam satu track. Biasanya DAT digunakan untuk musisi pemula dan live musik. Sementara DAW (Digital Audio Workstation) Terdiri dari beberapa perangkat yang digabungkan dan penyimpanannya berupa format midi. Track yang digunakan pun lebih dari satu, disesuaikan dengan peralatan penghasil suara yang digunakan dan kapasitas penyimpanan dari perangkat rekaman. Berdasarkan media penyimpanan tersebut, penelitian ini menggunakan media penyimpanan DAW (Digital Audio Workstation) yaitu software PreSonus Studio One 5. Gambar berikut merupakan tangkapan layar PreSonus Studio One 5.

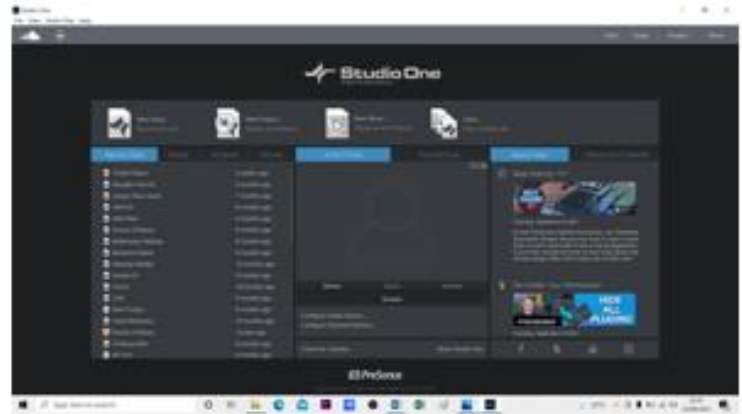

Gambar 10. Tangkapan Layar PreSonus Studio One 5 (Andiko, 2021)

Perekaman timbre Rapa'i buatan Fajar Siddiq menggunakan DAW PreSonus Studio One 5. Satusatunya DAW yang memungkinkan anda merekam, mencampur, memproduksi, menulis, menguasai, dan melakukan semuanya dari satu aplikasi intuitif. Tersedia mandiri atau sebagai bagian dari keanggotaan PreSonus Sphere. Lingkungan kerja satu jendela yang intuitif dengan fungsionalitas drag-and-drop yang cepat dan mudah serta dukungan multi-sentuh. Suite plugin Native Effects yang didesain ulang sepenuhnya. Trek audio dan instrumen tanpa batas, fitur otomatisasi canggih, instrumen virtual, bus, dan saluran FX. Emulasi konsol analog dengan kontrol overdrive, noise, dan bahkan crosstalk saluran yang sebenarnya, berkat pemrosesan lintas. Tampilan skor untuk pengeditan notasi tradisional, ditambah tablature dan notasi drum. Variasi suara memudahkan untuk mengontrol perpustakaan orkestra yang kompleks. (PreSonus. 2021). 
Proses rekaman musik terdapat beberapa tahapan yang dilakukan, yaitu: (1) Tracking, dari sebuah aransemen musik, tentunya ada instrumen yang akan mengiringi sebuah lagu. Setiap instrumen direkam dalam track, secara teknis adalah bunyi diubah menjadi gelombang magnetik kemudian sinyalnya diterima oleh recorder. Idealnya sumber suara (source) yang terekam semirip mungkin dengan aslinya. Jika menggunakan komputer (seperti sistem DAW) sinyal menjadi format midi. Tetapi oleh rekaman analog (seperti sistem DAT) sinyalnya tetap menjadi analog. (2) Overdub, adalah penambahan track rekaman baru pada track rekaman yang sudah ada. (3) Editing merupakan proses memindahkan, memotong, atau menyempurnakan bagian-bagian tertentu. Dalam dunia digital proses editing dilakukan dengan bantuan fasilitas software audio editing. (4) Mixing merupakan proses menggabungkan track rekaman yang telah dibuat dan menyeimbangkan semua track yang sudah direkam. (5) Equalizing, proses menciptakan karakter suara dengan penguatan atau pun pengurangan frekuensi suara seperti Low, Low-Mid, High-Mid dan High frekuensi. Proses ini menuntut ketajaman telinga dalam mendengar hingga antara frekuensi yang satu dengan yang lain tidak saling bertabrakan. Suara yang terekam harus memiliki kejernihan, terang dan tidak pecah. (6) Sound effect, memberikan karakter yang lebih kuat seperti efek Delay, Chorus, Compresi, Noise Gate, Limiter, dll. Sentuhan terakhir ini akan menjadikan musik siap untuk didengarkan setelah Mastering. (7) Mastering, Gunanya menghilangkan efek "hiss" dan "hum", menurunkan simbilance (ess) yang berlebihan, memadatkan frekuensi-frekuensi yang kasar, memoles, dan meratakan, menetapkan standar volume. Barulah musik karya kita direkam ke dalam pita kaset, CD, MP3 atau format lainnya agar dapat diputar dalam berbagai audio player. Dalam perekaman timbre Rapa'i buatan Fajar Siddiq, hanya menggunakan tahapan tracking dikarenakan kebutuhan rekaman yang original dari timbre tersebut. Gambar berikut merupakan tangkapan layar dari tahapan tracking perekaman timbre Rapa'i buatan Fajar Siddiq.

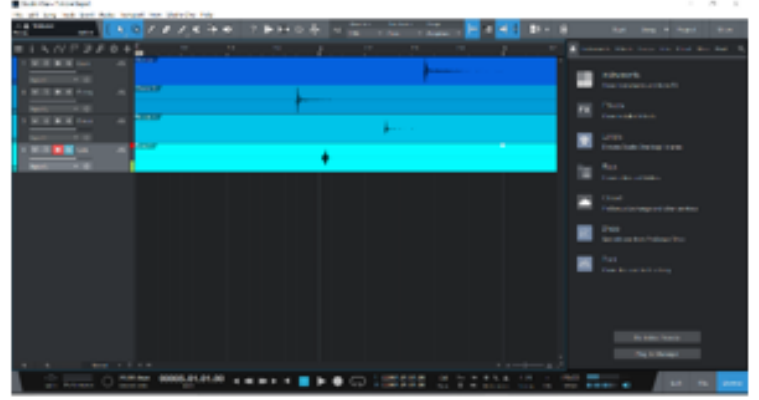

Gambar 11. Tangkapan Layar Tahapan Tracking (Andiko, 2021)
Gorga : Jurnal Seni Rupa

Volume 10 Nomor 02 Juli-Desember 2021

p-ISSN: 2301-5942 | e-ISSN: 2580-2380

Perekaman timbre Rapa'i buatan Fajar Siddiq menggunakan 4 channel dengan tipe rekam mono audio, sample rate $44.1 \mathrm{kHz}$ dan resolusi 24 bit. Suhu udara berkisar antara 30-31 derajat celcius pada saat perekaman hal ini juga berpengaruh pada membran dari Rapa'i yang terbuat kulit sapi. Solusinya posisi sedak disesuaikan dengan cuaca, saat cuaca panas sedak dipasang seperti biasanya dan saat cuaca dingin sedak dipasang lebih ketat agar dapat menghasilkan timbre seperti biasanya. Hal ini disebabkan kulit sapi mengalami pengendoran pada cuaca dingin dan pengaturan sedak menjadi tolak ukur untuk menghasilkan timbre yang sesuai dengan kondisi cuaca.

\section{2). Analisis Timbre Rapa'I Buatan Fajar Siddiq} Analisis timbre Rapa' $i$ buatan Fajar Siddiq di Desa Kayee Lheu ini menggunakan Spectrum Analyzer pada software musik PreSonus Studio One 5 Professional. Studio One 5 Professional adalah perangkat lunak DAW (Digital Audio Workstation) yang digunakan untuk membuat, merekam, menganalisis, mixing dan mastering musik. Perangkat lunak ini dibuat oleh PreSonus Software, Ltd. untuk OS X dan Windows. Spectrum Analyzer yang digunakan merupakan produk NUGEN Audio Visualyzer. Analisis ini dilakukan di home studio QZ Pro, Kota Jantho, Aceh Besar. Berikut ini tahapan analisis timbre Rapa' $i$ buatan Fajar Siddiq berdasarkan tangkapan layar yang dilampirkan.

(1). Tahap Pertama

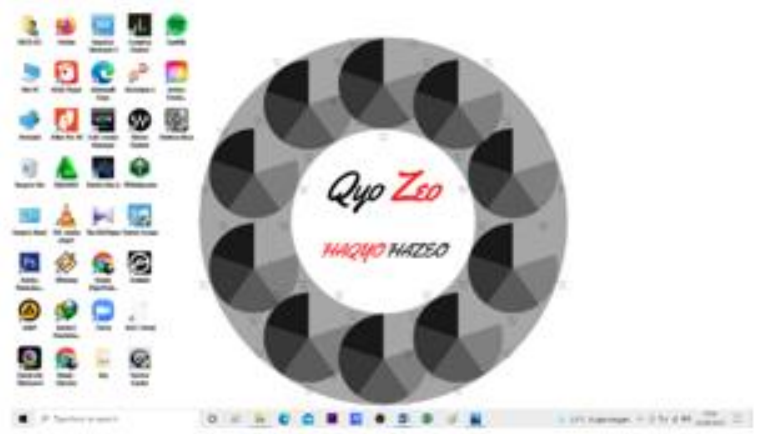

Gambar 12. Tangkapan Layar Tahapan Pertama (Andiko, 2021)

Tahapan pertama dalam analisis timbre Rapa'i buatan Fajar Siddiq masih menggunakan software musik PreSonus Studio One 5 Professional. Klik dua kali tampilan Studio One 5 pada desktop untuk memulai proses. Selanjutnya akan ada tampilan loading process PreSonus Studio One 5 Professional. 


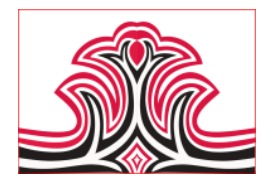

(2). Tahap Kedua

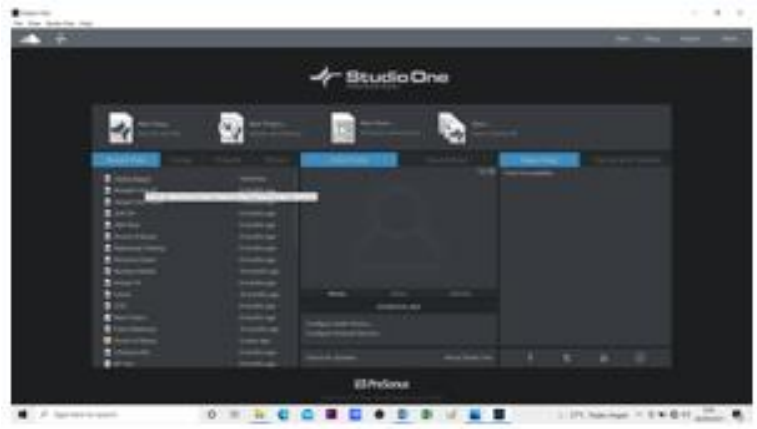

Gambar 13. Tangkapan Layar Tahapan Kedua (Andiko, 2021)

Tahapan kedua dalam analisis timbre Rapa'i buatan Fajar Siddiq menggunakan software musik PreSonus Studio One 5 Professional. Klik file Timbre Rapa'i pada bagian recent files PreSonus Studio One 5 Professional.

\section{(3). Tahap Ketiga}

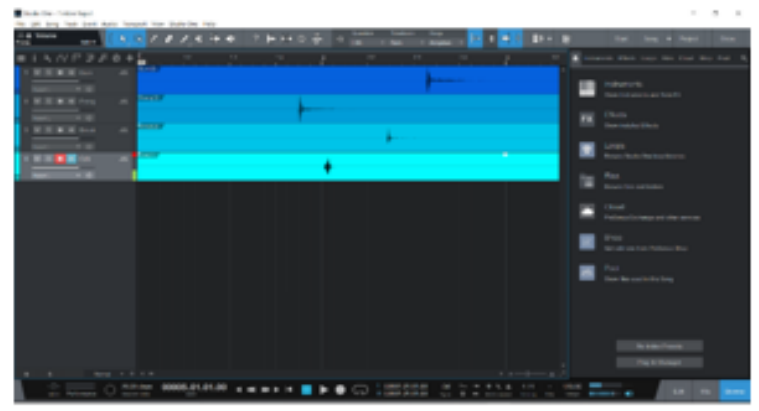

Gambar 14. Tangkapan Layar Tahapan Ketiga (Andiko, 2021)

Tahapan ketiga dalam analisis timbre Rapa'i buatan Fajar Siddiq menggunakan software musik PreSonus Studio One 5 Professional. Tampilan file timbre Rapa'i akan muncul seperti pada tahapan tracking.

\section{(4). Tahap Ke-empat}

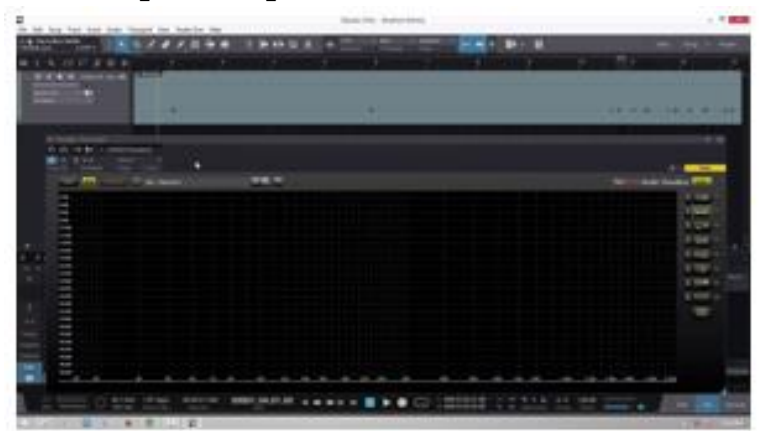

Gambar 15. Tangkapan Layar Tahapan Keempat (Andiko, 2021)

Tahapan ke-empat dalam analisis timbre Rapa'i buatan Fajar Siddiq menggunakan software musik PreSonus Studio One 5 Professional. Klik Post pada bagian kanan bawah tampilan, cari dan klik folder NUGEN
Gorga : Jurnal Seni Rupa

Volume 10 Nomor 02 Juli-Desember 2021 p-ISSN: 2301-5942 | e-ISSN: 2580-2380

Audio. Selanjutnya klik NUGEN Visualizer untuk memulai menganalisis timbre timbre Rapa'i buatan Fajar Siddiq.

Rapa'I merupakan instrumen perkusi dengan sumber bunyi dari material kayu dan kulit. Energi dipindahkan dari sumber bunyi Rapa'i dalam bentuk frekuensi bunyi longitudinal. Frekuensi berarti jumlah getaran yang terjadi dalam satu detik. Frekuensi diartikan sebagai jumlah perubahan tekanan dalam setiap detiknya atau frekuensi setiap detiknya dalam satuan cycles per second (cls) atau Hertz (Hz). Data analisis timbre Rapa' $i$ berupa kandungan bunyi yang terdiri dari frekuensi dan SPL (Sound Pressure Level).

SPL (Sound Pressure Level) merupakan tingkat tekanan suara digunakan untuk mengukur intensitas suara dan dijelaskan dalam desibel. Desibel (dB) adalah unit logaritmik yang menyatakan rasio tingkat tekanan suara yang diukur dengan tingkat referensi standar (Wijayanto, 2017). Frekuensi dan SPL dari timbre Rapa'i buatan Fajar Siddiq tidak bersifat mutlak, dalam hal ini analisis deskriptif berdasarkan hasil dari faktor-faktor yang diterapkan saat perekaman. Data timbre ini yang akan dijadikan data rujukan pembuatan Virtual Studio Technology (VST) Rapa'i buatan Fajar Siddiq. Berikut ini analisis deskriptif timbre Rapa'i buatan Fajar Siddiq.

\section{a. Frekuensi Timbre Dum Rapa'I Buatan Fajar Siddiq}

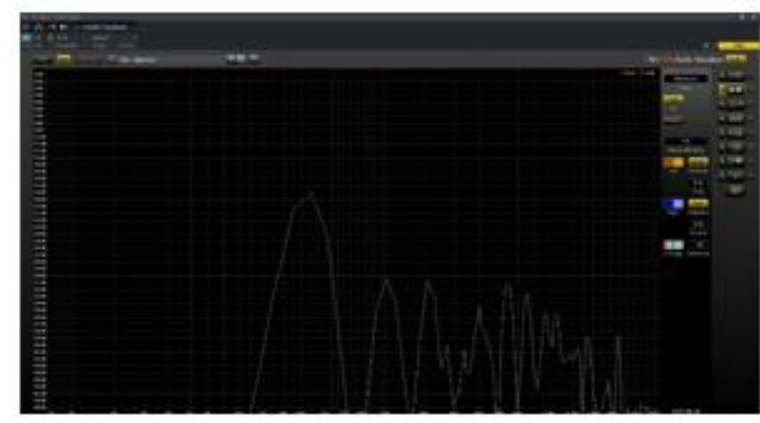

Gambar 16. Tampilan Visual Frekuensi Timbre Dum Rapa'i Buatan Fajar Siddiq (Andiko, 2021)

Berdasarkan tampilan visual tersebut pada sisi kanan atas terlihat frekuensi fundamental $172 \mathrm{~Hz}$ dengan SPL $-17,8 \mathrm{~dB}$. Terdapat sinyal audio pada frekuensi $300 \mathrm{~Hz}$ dengan SPL $-30,2 \mathrm{~dB} ; 400 \mathrm{~Hz}$ dengan SPL $30,7 \mathrm{~dB} ; 600 \mathrm{~Hz}$ dengan SPL $-34,3 \mathrm{~dB} ; 720 \mathrm{~Hz}$ dengan SPL $-31,4 \mathrm{~dB}, 815 \mathrm{~Hz}$ dengan SPL $-32,5 \mathrm{~dB} ; 990 \mathrm{~Hz}$ dengan SPL -35,4dB, 1330Hz dengan SPL -38,8dB; $1660 \mathrm{~Hz}$ dengan SPL -38,6dB. 
Frekuensi yang muncul setelah frekuensi fundamental merupakan sinyal-sinyal harmonik timbre dum dari Rapa'i buatan Fajar Siddiq. Sinyalsinyal tersebut merupakan pembentuk bunyi dengung frekuensi rendah yang menjadi ciri khas dari timbre dum. Timbre dum memiliki sensasi bunyi dengung yang bergetar, getaran yang dihasilkan berkarakter gelap. Gelap yang dimaksud disini bukan warna dalam artian corak rupa namun lebih kepada warna bunyi yang dihasilkan.

\section{b. Frekuensi Timbre Preng Rapa'I Buatan Fajar Siddiq}

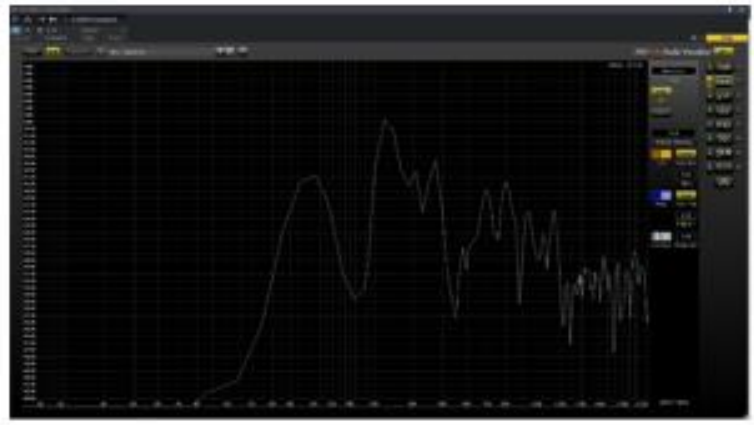

Gambar 17. Tampilan Visual Frekuensi Timbre Preng Rapa'i Buatan Fajar Siddic

(Andiko, 2021)

Berdasarkan tampilan visual tersebut pada sisi kanan atas terlihat frekuensi fundamental $192 \mathrm{~Hz}$ dengan SPL $-16,8 \mathrm{~dB}$. Terdapat sinyal pada frekuensi $320 \mathrm{~Hz}$ dengan SPL -8,6dB; $475 \mathrm{~Hz}$ dengan SPL $-14,5 \mathrm{~dB} ; 685 \mathrm{~Hz}$ dengan SPL $-18,9 \mathrm{~dB} ; 795 \mathrm{~Hz}$ dengan SPL -17,9dB; $945 \mathrm{~Hz}$ dengan SPL $-22,2 \mathrm{~dB} ; 1130 \mathrm{~Hz}$ dengan SPL $21,7 \mathrm{~dB} ; 1435 \mathrm{~Hz}$ dengan SPL $-30,2 \mathrm{~dB} ; 1660 \mathrm{~Hz}$ dengan SPL - 28,5dB.

Frekuensi yang muncul setelah frekuensi fundamental merupakan sinyal-sinyal harmonik timbre preng dari Rapa' $i$ buatan Fajar Siddiq. Sinyal-sinyal tersebut merupakan pembentuk bunyi dengung frekuensi tinggi yang menjadi ciri khas dari timbre preng. Timbre preng memiliki sensasi bunyi dengung yang nyaring, getaran yang dihasilkan berkarakter terang. Terang yang dimaksud disini bukan warna dalam artian corak rupa namun lebih kepada warna bunyi yang dihasilkan.
Gorga : Jurnal Seni Rupa

Volume 10 Nomor 02 Juli-Desember 2021 p-ISSN: 2301-5942 | e-ISSN: 2580-2380

\section{c. Frekuensi Timbre Breuk Rapa'I Buatan Fajar} Siddiq

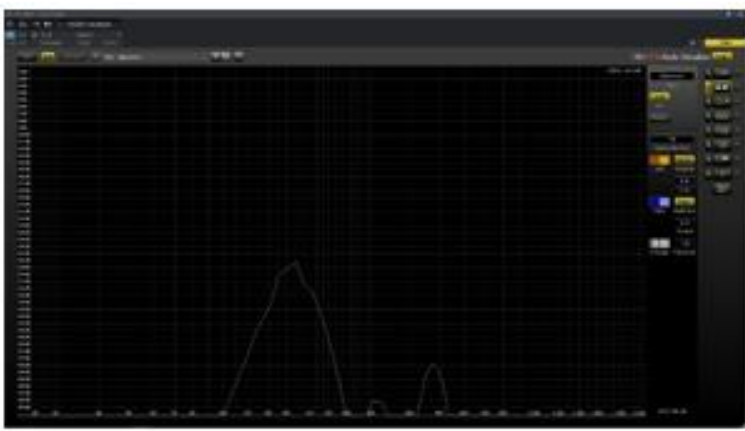

Gambar 18. Tampilan Visual Frekuensi Timbre Breuk Rapa'i Buatan Fajar Siddiq (Andiko, 2021)

Berdasarkan tampilan visual tersebut pada sisi kanan atas terlihat frekuensi fundamental $172 \mathrm{~Hz}$ dengan SPL $-28,2 \mathrm{~dB}$. Terdapat sinyal audio pada frekuensi $300 \mathrm{~Hz}$ dengan SPL -48,2dB dan 475Hz dengan SPL -42,8dB.

Frekuensi yang muncul setelah frekuensi fundamental merupakan sinyal-sinyal harmonik timbre breuk dari Rapa'i buatan Fajar Siddiq. Sinyal-sinyal tersebut merupakan pembentuk bunyi dengung frekuensi rendah yang menjadi ciri khas dari timbre breuk. Timbre breuk memiliki sensasi bunyi redam dengung, redam yang dihasilkan berkarakter gelap. Gelap yang dimaksud disini bukan warna dalam artian corak rupa namun lebih kepada warna bunyi yang dihasilkan.

\section{d. Frekuensi Timbre Crik Rapa'I Buatan Fajar Siddiq}

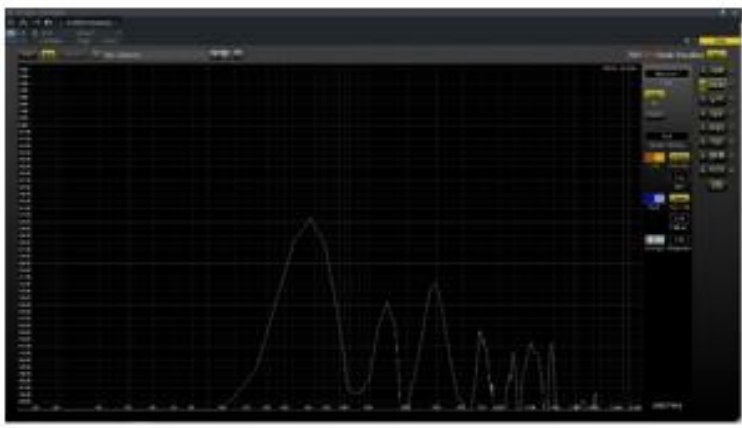

Gambar 19. Tampilan Visual Frekuensi Timbre Crik Rapa'i Buatan Fajar Siddiq (Andiko, 2021)

Berdasarkan tampilan visual tersebut pada sisi kanan atas terlihat frekuensi fundamental $192 \mathrm{~Hz}$ dengan SPL $-22,3 \mathrm{~dB}$. Terdapat sinyal pada frekuensi $345 \mathrm{~Hz}$ dengan SPL $-34,5 d B ; 495 \mathrm{~Hz}$ dengan SPL $-31,9 \mathrm{~dB} ; 690 \mathrm{~Hz}$ dengan SPL $-38,8 \mathrm{~dB} ; 880 \mathrm{~Hz}$ dengan SPL $-42,1 \mathrm{~dB}$; $1015 \mathrm{~Hz}$ dengan SPL $-40,5 \mathrm{~dB} ; 1180 \mathrm{~Hz}$ dengan SPL $40,4 \mathrm{~dB}$. 


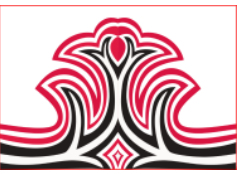

Frekuensi yang muncul setelah frekuensi fundamental merupakan sinyal-sinyal harmonik timbre crik dari Rapa'i buatan Fajar Siddiq. Sinyal-sinyal tersebut merupakan pembentuk bunyi nyaring frekuensi tinggi yang menjadi ciri khas dari timbre crik. Timbre crik memiliki sensasi bunyi gemerincing, bunyi yang dihasilkan berkarakter terang. Gelap yang dimaksud disini bukan warna dalam artian corak rupa namun lebih kepada warna bunyi yang dihasilkan.

\section{KESIMPULAN DAN SARAN}

\section{Kesimpulan}

Data timbre Rapa'i buatan Fajar Siddiq pada penelitian ini merupakan hasil dari unsur-unsur perekaman yang diterapkan. Penggunaan peralatan perekaman yang terdiri dari mikrofon condenser Audio Technica AT2035, audio interface ZOOM R24 (Zoomtech, 2021). dan media penyimpan menggunakan $D A W$ (Digital Audio Workstation) yaitu PreSonus Studio One 5 juga mempengaruhi perekaman timbre Rapa'i buatan Fajar Siddiq. Teknik rekaman multitrack dengan track yang terpisah dari timbre Rapa'i buatan Fajar Siddiq. Timbre dum memiliki sensasi bunyi dengung yang bergetar, getaran yang dihasilkan berkarakter gelap. Timbre preng memiliki sensasi bunyi dengung yang nyaring, getaran yang dihasilkan berkarakter terang. Timbre breuk memiliki sensasi bunyi redam dengung, redam yang dihasilkan berkarakter gelap. Timbre crik memiliki sensasi bunyi gemerincing, bunyi yang dihasilkan berkarakter terang. Timbre Rapa'i buatan Fajar Siddiq yang terdiri dari data nilai frekuensi dan SPL empat warna bunyi (dum, preng, breuk dan crik) tersebut merupakan rujukan pembuatan VST (Virtual Studio Technologi) Rapa'i buatan Fajar Siddiq.

\section{Saran}

Fajar Siddiq merupakan satu-satunya pengrajin alatalat musik Aceh khususnya Rapa'i. Keterbatasan peralatan khusus tidak menghalangi semangat Fajar Siddiq memproduksi Rapa'i. Selama kurang lebih 27 tahun ratusan Rapa'i diproduksi oleh tangan terampilnya. Hal ini harus menjadi catatan bsgi pemerintah khususnya daerah-daerah yang memanfaatkan jasa pembuatan alat-alat musik Aceh dari Fajar Siddiq. Khususnya Kabupaten Aceh Besar dan Kota Banda Aceh.

Beberapa saran yang nantinya dapat menjadi bahan pertimbangan bagi dinas dan lembaga terkait yaitu: Fajar Siddiq sebagai bagian dari keberlanjutan seni budaya yang menggunakan alat-alat musik Aceh. Tanpa alat-alat musik tersebut bisa mengancam mata rantai seni budaya di masa depan. Program-program
Gorga : Jurnal Seni Rupa

Volume 10 Nomor 02 Juli-Desember 2021

p-ISSN: 2301-5942 | e-ISSN: 2580-2380

pengadaan peralatan yang lebih modern dan workshop pembuatan alat-alat musik Aceh merupakan langkah tepat untuk proses keberlajutan dan kemajuan kebudayaan.

\section{DAFTAR RUJUKAN}

Andiko, Benny. (2021). "Timbre Rapa'I". Hasil Dokumentasi Pribadi: 12 September 2021, Desa Kayee Lheu.

Bartlett, Bruce dan Jenny Bartlett. (2009). Practical Recording Techniques. Burlington: Elsevier.

Ediwar. (2016). Rekonstruksi dan Revitalisasi Kesenian Rapa'I Aceh Pasca Tsunami. Resital, 17(1), 30-45.

Huber, David. M. \& Rustein, Robert. E. (2017). Modern Recording Techniques. Routledge: Focus Press.

Lefaan, Ambrosius Yuniart. (2010). Studio Rekaman Musik di Yogyakarta. S1 Thesis. Yogyakarta: UAJY.

Rossing, Thomas. D. (2002). The Science of Sound. Routledge: Focal Press.

Rumsey, Francais. \& McCormick, Tim. (2009). Sound and Recording: Applications and Theory (Audio Engineering Society Presents). Routledge: Focal Press.

Sadiman, Arif. S. (2000). Peran Teknologi dalam Meningkatkan Mutu Pendidikan Dasar. Jakarta: Teknodik.

Siddiq, Fajar. (2021). "Timbre Rapa'I". Hasil Wawancara Pribadi: 12 September 2021, Desa Kayee Lheu.

Technica, Audio. (2021). Cardioid Condenser Microphone AT2035. https://www.audiotechnica.com/en-us/at2035 (diakses tanggal 7 Juli 2021).

Walzer, Michael. (1997). On Toleration: Castle Lectures in Ethics, Politics, and Economics. Yale: University Press.

Wijayanto. (2017). Analysis of Sound Pressure Level (SPL) and Lay Out of Engines in The Factory. Media Mesin, 8(1), 38-44.

Zoomtech. (2021). Audio Interface Zoom R24. https://zoomcorp.com/en/us/digital-mixer-multitrack-recorders/multi-track-recorders/r24/ (diakses tanggal 7 Juli 2021). 